条件を併記した。

即ち上記 3 專項及び 5 つ砥石因子から砥石 磨耗の全㥞が説明し得るものと思う。

\section{8. 結言}

以上の報告惠項を要約すれば

1）砥石の磨耗経過と乞の形態汢大別して四 種に分けられるるのであるてとを述べ

2）磨耗之各砥石因子（砥粒, 粒度, 結合度, 組織, 結合剤) 之の関係を明かにし

3）更に以上の両者の関係!及潘す研削条件 （切込，送り，加工物速度，砥石速度，砥石の 巾，冷却剩の使用）の影響を確かめ

4）磨耗之砥石及び研削条件之の関係に就い ての理論的疗考察を試み

5）最後に砥石磨耗を支配する3つの事項之 てれに関係する 5 つの砥石因子を挙げて総合的 な磨耗の説明をした。
参 照 交 献

1) 洨辺半十：精密機械 8 卷 10 号 (昭 27-10) (第政)

2）塩崎 進：マシナリー誌 (昭25一9) p.10〜13.

3) 渡辺牛十：精密機械 18 卷 8 号 (昭 27-3) （第 I 報）

4）10）大越，渡辺：機械試験所々報 6 参 3 号 (昭 27-3)

5) R. Woxén: The Royal Swedish Institute for Engineering Research Proceedıng No. 124 1933 (工作機械に関する資料 7 卷 $7,8,9$ 㕺)

6）牧野孝一：日本機械学会誌（昭 19-4） p, 169 .

7) 熊谷直次㿟：精密機械 9 卷 5 号 (昭 17-5)

8）津和秀夫：精密機械 17 卷 9 号 (和 26-9)

9) H.W. Wagner; Mechanical Engineering, (March-1950) p. 225.

Norton "Grits and Grinds" No. 3 \& 10 Vol. $41(1950)$

\title{
銅系合金ダイカスト鑄物の縮み代に就て
}

$621.74 .0+3$

\author{
正会負太界信之 \\ Shrinkage of Copper-Base Alloy Die-Castings \\ Ncbuyuki Ohta
}

The copper-base alloys used in this report are as follows; (a) yellow brass (Cu 60\%, $\mathrm{Zn} \mathrm{40 \% ),}$ (b) lead brass ( $\mathrm{Cu} 58 \%, \mathrm{Zn} \mathrm{40 \% ,Pb} \mathrm{2 \% ),} \mathrm{(c)} \mathrm{tombasil} \mathrm{(Cu} \mathrm{83 \% ,} \mathrm{Zn} \mathrm{13 \% ,} \mathrm{Si} \mathrm{4 \% ).} \mathrm{Length} \mathrm{of}$ hollow space in die is measured by a block gauge, while die-castings are measured by a measuring machine. Accordingly, the shrinkage is decided from the difference between these two dimensions. This experiment shows how the shrinkage is influenced by the casting temperature, the castıng pressure, and the temperature of die. On the other hand, the blow hole and surface of diecastings are tested about the above specimens.

\section{1. 緒言}

錫系合金，ザマック合金，アルミニウム系合 金のダイカスト鑄物の縮多代に就ては，既に本 誌上に発表11233) した。本論文に䄪ては，銅系

1) 精密機械 第 9 卷第 6 号 p. 9

2）精密機械 第 15 卷第 8 号 p. 15

3）精密機械 第 16 卷第 4 号 p. 5 .
合金，即ち四六真镭，挽物用真鍮，トムバジ几 の三種類のダイカスト鑄物の縮夕代を，鑄込圧 力，鑄込溫度，型の溫度を変えて，求め，型設 計の資料を提供している。本研究の試片を利用 して，鑄肌及び鑄巢の問題!及んでいる。

\section{2. 実 験 設 備}

ダイカスト機械及び実験設備注前研究に使用 
したものである。金型も以前に使用したもので あるが，湯口の厚さが $0.56 \mathrm{~mm}$ では，湯が湯 口から型內の空吵に噴出するととが出来ないの で，てれを $1.64 \mathrm{~mm}$ に拡げている。佮祘試 を鑄造する 型內の 空隙の長さは, $100.115 \mathrm{~mm}$ である。

\section{3. 試片}

試片はすべてダイカストで製作している。試 片の配合成分注表1に示した通りである。但し

表 1 合金の成分

\begin{tabular}{l|l|l|l|l}
\hline & $\mathrm{Cn}$ & $\mathrm{Zn}$ & $\mathrm{Pb}$ & $\mathrm{Si}$ \\
\hline 四六眞鍮 & 58.8 & 41.2 & & \\
掩物用眞䤣 & 57.01 & 40.7 & 2.29 & \\
トムベジル & 82.87 & 12.95 & & 4.18 \\
\hline
\end{tabular}

四六真鍮には，亞鉛の蒸発を防ぐために， $\mathrm{Al} の$ $0.04 \%$ を混入し, 又型に鑄物の粘着を防ぐを めに， $\mathrm{Pb} 0.5 \%$ を入れている。挽物用真鍮 に多亞鉛の蒸発を防ぐために，Alの0.04\%を 大れている。

\section{4. 実 驗 結 果}

〔A〕. 鑄込材料 表 2 の如く, 縮夕代沬, 鑄 込材料によつて大差をいが, 挽物用真鍮が一番 大きくて，一番小さい四六真鍮に比較すると， $100 \mathrm{~mm}$ について, $0.13 \mathrm{~mm}$ ばかり大きい。ト ムバジルは此の中間にある銅系合金のダイカ スト鑄物の型を設計する際には，此の三つの合 金の平均 $1.194 \mathrm{~mm}$ に取り,てれを此の三つの 合金のすべてに使用してよい。

\section{表 2 縮 み 代 (mm)}

鑄込圧力 $=150 \mathrm{~atm}$ 型刀溫度 $=70^{\circ} \mathrm{C}$ 試片の長さ $=100 \mathrm{~mm}$

\begin{tabular}{|c|c|c|c|c|}
\hline 鑄込温度 $\left({ }^{\circ} \mathrm{C}\right)$ & 910 & 950 & 990 & 平均 \\
\hline 四六 寅 鍮 & 1.133 & 1.142 & 1.125 & 1.133 \\
\hline 捚物用德鍮 & 1.279 & 1.252 & 1.256 & 1.262 \\
\hline トムベジル & 1.176 & 1.208 & 1. 176 & 1.188 \\
\hline
\end{tabular}

〔B]鑄込溫度 表 2 に示す如く, 縮夕代は てれに殆んぞ影響されない。但し鑄込溫度が低 すぎるときは，非常に小さい鑄物，即ち縮久代
の大きい鑄物が出来る傾向がある。

[C]鑄込圧力 ての影響仿, 表了に示す如 く，余り明かでをい。大体に於て，鑄込圧力の 大きい程，縮多代が小さくなる様である。此の 場合多鑄込圧力が低い之小さい鑄物分出来る傾 向がある。即ち縮多代が大学くなる傾向があ る。

表 3 縮 み 代 $(\mathrm{mm})$

鑄达溫度 $=910^{\circ} \mathrm{C}$ 型の溫度 $=70^{\circ} \mathrm{C}$ 試片の長さ $=100 \mathrm{~mm}$

\begin{tabular}{c|c|c|c}
\hline 鑄込圧力 (atm) & 70 & 150 & 250 \\
\hline 四六眞 鍮 & 1.262 & 1.133 & 1.058 \\
掩物用異鍮 & 1.284 & 1.279 & 1.250 \\
トムバジル & 1.220 & 1.176 & 1.174 \\
\hline
\end{tabular}

表 4 縮 み 代 ( $\mathrm{mm}$ ) 鑄込圧力 $=150 \mathrm{~atm}$ 鋀込溫度 $=910^{\circ} \mathrm{C}$ 試片の長さ $=100 \mathrm{~mm}$

\begin{tabular}{|c|c|c|c|}
\hline 型の溫度 $\left({ }^{\circ} \mathrm{C}\right)$ & 70 & 160 & 240 \\
\hline 四宍畺 鍮 & 1.133 & 1.036 & 1.021 \\
\hline 掩物用寡鍮 & 1.279 & 1.104 & 0.903 \\
\hline トムバジル & 1.176 & 1.032 & 0.999 \\
\hline
\end{tabular}

〔D〕型の溫度 此の影響は，表 4 の如く， 顯著である。即ち型の溫度が上昇する程, 縮 み代が小さくなつている。てれ汢大体に於て， 型の熱膨脹によるとと注先に述べを通りであ $3^{4)}$ 。

縮多代汢大体に於て， $l_{20}\left\{\alpha\left(t_{s}-20\right)-\alpha_{f}\right.$ $\left.\left(t_{f}-20\right)\right\}$ によつて算出出来了ことは先に述べ た5)。式中の $l_{20}$ 溫度 $20^{\circ} \mathrm{C}$ に於汀当型の寸 法, $\alpha$ 江鑄込材料の膨脹係数， $\alpha_{f}$ 江型材の膨 脹係数, $t_{s}$ 江凝固完了溫度, $t_{f}$ 汒型の溫度であ

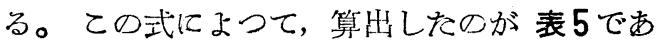
る。ての值注実験によつて求めてりのよりも,

表 5 四六寡鍮つ算定綰み代

\begin{tabular}{c|c|c|c|c|c|c} 
& \multicolumn{5}{c}{ (長さ $100 \mathrm{~mm}$ について) } \\
\hline $\begin{array}{c}\text { 型の溫度 } \\
\left({ }^{\circ} \mathrm{C}\right)\end{array}$ & 300 & 250 & 200 & 150 & 100 & 50 \\
\hline $\begin{array}{c}\text { 縮 } \\
(\mathrm{mm})\end{array}$ & 1.12 & 1.18 & 1.24 & 1.29 & 1.35 & 1.41 \\
\hline
\end{tabular}

4）精密機械 第 15 卷 第 8 号 p. 15

5) 精密機械第 16 卷第 4 它 p. 7 
少し大きく出ている。ての相違について考えて 見るに，前記の算式は，湯口の湯が凝固する己 きに，型內のすべての部分は，湯口之同一溫度 にあるもの之仮定しているが，然し型內の鑄物 柱既に凝固して，溫度の相当低い部分があるも のと思われる。てれが実際に求めた縮み代が， 算式により求めたものより少し小さくなる 理由であると思われる。

\section{4. 鋳巢}

表 67 ，8 亿示す如く, 巢江鑄造条件, 即ち 鑄込圧力，鑄込溫度，型の溫度に殆九ど関係な

表 6 巢 の 割合 $(\%)$

镗达圧力 $=150 \mathrm{~atm}$ 型の溫度 $=70^{\circ} \mathrm{C}$ 試片の長さ $=100 \mathrm{~mm}$

\begin{tabular}{|c|c|c|c|}
\hline 銈込溫度 $\left({ }^{\circ} \mathrm{C}\right)$ & 910 & 950 & 990 \\
\hline 四六眞 鍮 & 5.14 & 4.58 & 3.55 \\
\hline 招物用德錄 & 5.77 & 5.69 & 5.41 \\
\hline トムバジル & 4.66 & 4.91 & 4.47 \\
\hline
\end{tabular}

表 7 巢の割合 $(\%)$

錆込溫度 $=910^{\circ} \mathrm{C}$ 型の溫度 $=70^{\circ} \mathrm{C}$ 試片の長さ $=100 \mathrm{~mm}$

\begin{tabular}{|c|c|c|c|}
\hline 鋀込圧力 (atm) & 70 & 150 & 250 \\
\hline 四六真 鍮 & 3.18 & 5.14 & 5. 17 \\
\hline 捚物用面鍮 & 6.43 & 5.77 & 4.87 \\
\hline トムバジル & 5.96 & 4.66 & 4. 37 \\
\hline
\end{tabular}

表 8 巢 の 割 合 $(\%)$

鑄込圧力 $=150 \mathrm{~atm}$ 鑄込溫度 $=910^{\circ} \mathrm{C}$ 試片の長さ $=100 \mathrm{~mm}$

\begin{tabular}{|c|c|c|c|}
\hline 型の溫变 $\left({ }^{\circ} \mathrm{C}\right)$ & 70 & 160 & 240 \\
\hline 四六㬝铨 & 5.14 & 4.77 & 3.92 \\
\hline 掩物用吠堬 & 5.77 & 5.22 & 4.77 \\
\hline トムバジル & 4.66 & 5.21 & 5.43 \\
\hline
\end{tabular}

い。只鑄込圧力の極端:

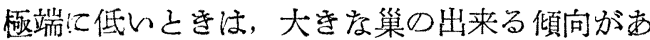
る。図1注。湯口に直角に, 縱方向に中央で, 切断しを面の巢を示す。三種の合金共!，巢に 大差索い。此の場合には, 縱方向に大体一様! 巢が散布している。今迄の研究では, 巢注大体

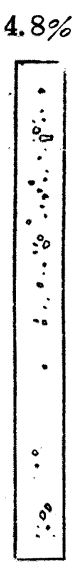

$\mathrm{C}$
$5.2 \%$

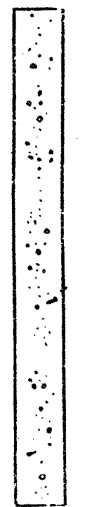

$B$
$4.6 \%$

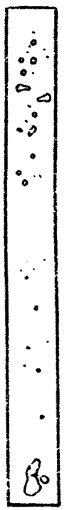

A
に湯口の反対側に圧迫さ れているが, 此の場合に は，前述の通りである。 その理由は，湯口を厚く したためか, ·或は銅系合 金のためか不明である。

\section{5. 籌 肌}

鑄肌はトムバジルがー 番綺麗で，その表面は鎈 造条件に殆えぞ関係な く，鏡面の如く滑かで西 る。挽物用真鍮が一番粗 で、ザラザラした表面を 温度 $950^{\circ}$ 型の溫度 $70^{\circ}$ 湯口 右上网 $\mathrm{A}=46$ 眞鍮 $B=$ 强物用暝鍮 $\mathrm{C}=$ トムバシ

図1巢 9 狀況 している。四六真鍮法, 挽物用真鍮よりよいが, 大体气れ之似を表面を している。鑄达溫度の高い程，何れるとの表面 ほ綺麗になる。トムバジ几注鑄込溫度の影響少 く, 常に綺麗である。

挽物用真鍮拄，鑄达溫度の上昇と共に，その 表面注聮著によくなる。四六真鑄㤌てれに次い

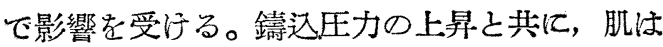
綺麗となる。挽物用真鍮! 於ては 鑄込圧力の 影響が顯著で，四六真鍮は，てれに次ぎ，トム バジルには，その影響がない。型の溫度の上昇 により，肌注綺麗になる傾向があるが，何れの 合金も、その影響汇顯著でない。トムバジルは

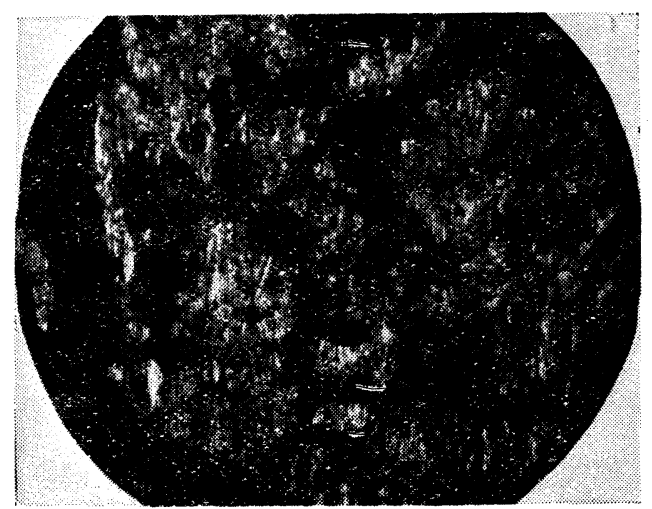

図 2 鑄物表面の顯微鏡㝍黃 ( $\times 128$ 但し原図縮少奖 $2 / 3$ )

録込圧力 $70 \mathrm{~atm}$ 鑄込温度 $910^{\circ} \mathrm{C}$ 型刀溫度 $70^{\circ} \mathrm{C}$ 鑄込材料 四六苜鍮 


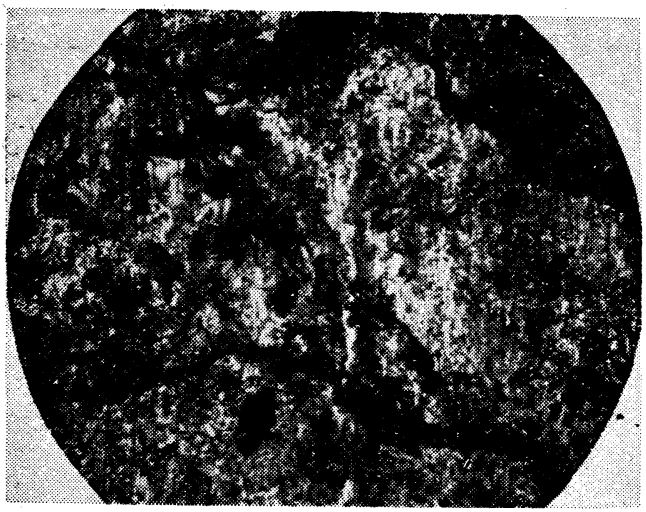

図 3 鑄物表面の顯微鏡㝍眞 (×128 但し原济縮少奖 2/3)

鎬込圧力 $150 \mathrm{~atm}$ 鑄込溫度 $993^{\circ} \mathrm{C}$ 型》温度 $70^{\circ} \mathrm{C}$ 鑄込材料 四六旦鍮

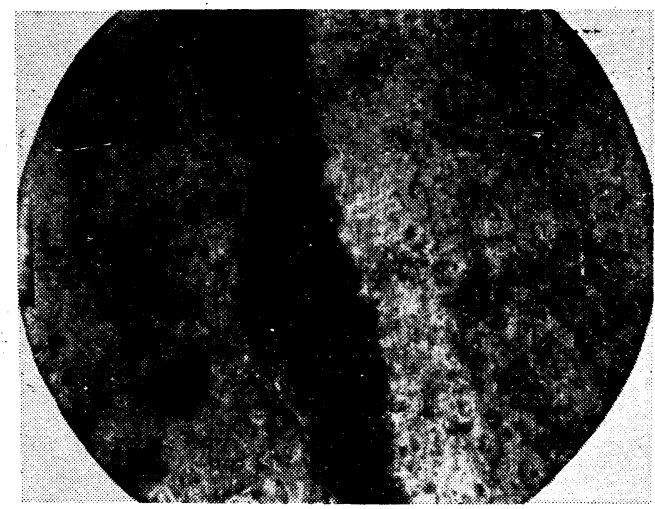

図 4 鑄物表面す㙷微鏡㝍異 (×128 但し原汶縮少慗 $2 / 3$ )

鑄込圧力 $70 \mathrm{~atm}$ 䥂込溫度 $910 \div \mathrm{C}$ 型刀溫度 $70^{\circ} \mathrm{C}$ 鑄込材料 トムバジル

僅かに肌が改善与る。四六真鍮, 挽物用真鍮 は, 型の溫度の影響が殆んどない。次に鑄物の 表面の顯微鏡写真を見るに; 図 2，3，4の通り である。図 2 に於て, 型剈に湯が激突して, 粉 霧状に飛散し，メタリコンの如く，壁に貼り付
く。各粒子に熱方不足して，相互!融合してい 度い。湯の溫度の低い場合!汇，鑄物の面は， 此の様を肌を示す部分が多い。湯の溫度の低い 之き汒，型の溫度が変つてり，鑄资压力が変つ て当，此の様存肌の部分が多い。四六真鍮，挽物 用真鍮に沬，此の様な粗い肌が現われている。 四六真鍮の鑄泛溫度が高い之，図了の如学肌が 現われる。湯に充分な熱があるから，後から来 を湯によつて，肌分゙移動し，静圧によつて，押 し付けられて 各粒子驾融合している。最後に トムバジルの場合㳉 大体に，肌誌非常に滑加 であるが，図40如く，湯が融合しない溝が現 わ好ている。トムバジルの鑄肌がずつと勝つて いる理由注 凝固の完了溫度がずこと低いため と思われる。

\section{6. 結 論}

（1）銅系合金の縮み代汒， $100 \mathrm{~mm}$ に就て, $1.194 \mathrm{~mm}$ 程度で, 挽物用真鍮が一番大をくて, 四六真鍮㤁一番小さん。鋞込溫度注縮み代に影 響存く，型の溫度の影響が一番大きい。

（2）トムバジ几の鑄肌注非常に綺麗て，婏 物用真鍮の肌が-番粗い。四六真鍮の肌注挽物 用真鍮の肌より它よい。

（3）四六真鍮，挽物用真鍮に於て，肌法鑄 込溫度，鑄込圧力の上昇によつて非常!改善さ れ，型の溫度の影響汢ない。

本研究注文部省の科学研究貴!てさつもの で本研究! 日立工機株式会社戶倉正雄，安保 順作氏，日立製作所多賀工場丹浩平氏の援助を 受けた。此処!此等の方々に厚く御礼を述べ 当。 